\title{
Higher Education Bilingual Programmes in Spain
}

\author{
Ana María Ramos García \\ University of Granada
}

Received: 17 January 2012 / Accepted: 22 May 2012

ISSN: $1697-7467$

\begin{abstract}
The purpose of this contribution is to summarize and put together information about which Spanish universities have started Bilingual or Multilingual Programmes and offer courses in foreign languages for their undergraduate courses. The current situation in our country, where primary and secondary bilingual programmes are being established all along our geography, makes necessary a move from higher education institutions in the form of Bilingual or Plurilingual Programmes so that those bilingual students will be able to continue their bilingual education at university level.

Keywords: higher education, bilingual/multilingual programmes, Spanish universities, CLIL

\section{Programas bilingües en la Educación Superior en España}

RESUMEN: El propósito de este artículo es recopilar y sintetizar información sobre las universidades españolas que han implantado programas bilingües o multilingües y ofrecen asignaturas en lenguas extranjeras para los grados. La situación actual en nuestro país, en el que se están implantando programas bilingües en primaria y secundaria en toda la geografía española, hace necesaria una respuesta por parte de las instituciones de educación superior, esto es, programas bilingües o plurilingües para que esos estudiantes bilingües puedan continuar su formación bilingüe en la universidad.

Palabras clave: educación superior, programas bilingües/multilingües, universidades españolas, AICLE
\end{abstract}

\section{InTRODUCTION}

The different regional administrations on education in Spain have made a huge effort in setting bilingual or plurilingual programmes in Primary and Secondary Education. The results have shown to be positive in recent pieces of research (Lorenzo, Casal and Moore, 2010; Barrios, 2010; Lasagabaster and Ruiz de Zarobe, 2010; Madrid and Hughes, 2011). It is the natural thing to go a step beyond and implement bilingual (or multilingual) programmes in higher education where there has been a tradition of offering postgraduate courses in foreign languages (mainly in English). Thus, the University of Granada offers three masters in English, seven bilingual (50\% English and Spanish) and two postgraduate degrees in which there are some courses in English. On the contrary, undergraduate bilingual offer is restricted to the degree in Primary Education. 
On the one hand Spanish primary and secondary educational context nowadays demands the existence of a wide range of degrees in a foreign language. It would be no sense in having primary and secondary bilingual programmes and postgraduate courses in English without bridging the gap between both. On the other hand, the need for internationalization of Spanish universities demands from students a better command of foreign languages.

\section{Context for bilingual/Plurilingual programmes}

There are several bilingual communities in which there are two co-official languages, but most of them are monolingual. This opposition in concept arises differences in the approaches towards 'bilingualism' in education, in the aforementioned cases it is a real example of plurilingualism: there is a bilingual context in which students are in contact with two languages in their everyday life and of course, at school. Besides, they study a third language (and later on a fourth one). So, bilingual or multilingual education has been a reality in this country for the last decades, although in different degrees depending on the area.

There have been immersion programmes which consisted in teaching several subjects in the co-official language (Science, Geography, and so on, and the Language itself and its Literature) to cater for both languages in the official curriculum. The case in monolingual communities is different. In those, students are introduced to the second language (or foreign language, what would be more accurate in that context) at school. Therefore, contextual differences should be pointed out: it is different to establish a bi/multilingual programme in a bilingual setting (i.e. a bilingual community) from establishing it in a monolingual setting. Contextual differences - which may seem unimportant - should be borne in mind. In a monolingual setting students may not have the opportunity to use the language in context outside school, and they are not used to the coexistence of two languages. This has a positive and a negative side. The positive one is that those problems derived from having languages in contact are not present, i.e.: pre-eminence of one language, social prestige connected to languages, etc., and the negative is that the 'second language' or foreign language can be seen as something distant, something which is not part of our own culture, but those feelings may be overcome by the fact that learning and using the language may be a source of better opportunities in their future life.

The move towards Content Language Integrated Learning (CLIL) programmes in primary and secondary education promoted and backed by regional administrations has fostered collaboration among teachers in the same course year; there were no CLIL materials, therefore they had to design their own activities and materials for the classroom. Well-known foreign language publishers have started to offer CLIL textbooks for those subjects which are taught in the foreign language ${ }^{1}$. But, it would be advisable to go on that path of designing specific materials and being less dependent on textbooks.

\footnotetext{
${ }^{1}$ Some of them are the following: Amco Iberia, Cambridge University Press, Heinle/SGEL Libros, Macmillan, Oxford University Press, Pearson Longman or Richmond Publishing/Santillana.
} 


\section{Bilingual/Plurilingual Programmes in Higher EdUCATION}

There are seventeen autonomous communities and seventy seven universities in Spain; the distribution of universities along the country is irregular ${ }^{2}$. Two thirds are state-funded and the rest are private ones, seven of which are religious. Thirty-three of them include bilingual (or plurilingual) programmes in their undergraduate courses.

There are some universities which only offer some degrees in English, but most of them offer both a Spanish and an English version of the degree and students are entitled to choose their best option, the whole degree can be taken in one language or the other. Others are 'bilingual: Spanish-English' which means that part of that degree, usually at least $50 \%$, is taken in the foreign language and the rest in the mother language; so, students may not have the possibility of selecting which English /Spanish courses they want to take.

In the following pages we will refer to both as 'English' and/or 'bilingual' according to the information gathered from universities and other sources. Therefore, no difference is made regarding the approach followed by each university when designing a bilingual or plurilingual programme and establishing bilingual education, it is understood in a broad sense, we have considered any course which is taught in the foreign language whether it is part of a bilingual degree or of a degree fully taught in the foreign language or a degree mostly in Spanish. The underlying idea is that what is important, in this case in our humble opinion, is the fact that universities offer the possibility of choosing courses in another language.

Postgraduate courses have not been taken into account as they are out of the scope of the present contribution as there has been a wider tradition of having postgraduate courses in foreign languages than undergraduate ones. This tendency is changing now with an explosion of bilingual options for students as it will be detailed in the following paragraphs.

This paper only tries to shed light on the matter in order to know what universities are doing to ensure their students an education which meets social current professional standards. The universities listed below are only those which offer any bilingual degree and/or courses in a foreign language (neither Spanish nor co-official languages in bilingual communities). The most common language of tuition in bilingual degrees is English, although there are some courses in French, German, and/or Italian.

\subsection{Antonio de Nebrija University}

This university offers thirteen bilingual degrees: American Law Program, Business Administration and Management, International Relations, European Business Programme, American Business Program, Tourism, Marketing and Communication, Advertising, Audiovisual Communication, Journalism, Primary and Pre-Primary Education. Besides, the Polytechnic School (Architecture, Industrial Design, Engineering) and the Faculty of Arts and Letters (Fine Arts, Performing Arts, Modern Languages, Translation) offer courses in English.

2 Andalucia (10), Aragón (2), Canarias (2), Cantabria (2), Castilla La Mancha (1), Castilla y León (9), Catalunya (12), Comunidad de Madrid (15), Comunidad Foral de Navarra (2), Comunidad Valenciana (8), Extremadura (1), Galicia (3), Illes Balears (1), La Rioja (2), País Vasco (3), Principado de Asturias (1) and Región de Murcia (3): http://www.mecd.gob.es/educacion/universidades/educacion-superior-universitaria/ que-estudiar-donde/universidades-espanolas.html 


\subsection{Autonomous University of Barcelona}

Two degrees related to business: Business Management and Communication, Business Administration and Management.

\subsection{CEU Abat Oliba University}

The two bilingual degrees which are offered at CEU Abat Oliba University are Journalism and Primary Education.

\subsection{CEU Cardenal Herrera University}

The degree in Odontology at this university is bilingual.

\subsection{Charles III University}

Students can choose among thirty six degrees (Arts and Humanities, Social and Legal Sciences and Engineering and Architecture) two of which may be taken in English and fourteen may be either bilingual, in Spanish, or in English. Those degrees which are only available in English are: Aerospace Engineering and Biomedical Engineering. Bilingual ones are: Electric Engineering, Industrial Electronic and Automatic Engineering, Computer Engineering, Mechanical Engineering, Audiovisual System Engineering, Communication Systems Engineering, Industrial Technology Engineering, Telematics Engineering, Business Administration, Audiovisual Communication, Economics, Accounting and Finance and Journalism. Out of all the degrees which can be taken at Charles III University, 5.5\% is taught in English, and $38.8 \%$ are bilingual, which implies that almost half of the offered studies are taught in a foreign language.

\subsection{Complutense University of Madrid}

Three degrees can be taken in English: Psychology, Business Administration and Economics; one of the two groups offered for each degree is in English. Apart from that, there is the possibility of taking Pre-Primary and Primary Education as bilingual degrees, which are offered at the Complutense and also at its two attached schools: EU Escuni and CES Don Bosco. In addition, law students can take a two-year specialization or 'mención' in 'French Law' which is indeed taught in French.

\subsection{Francisco de Vitoria University}

Business Administration is a bilingual degree in which students take more than half of their courses in English.

\subsection{IE University}

There are six degrees in English: Tourism Management, Art History, Biology, Communication, International Relations, and Psychology; and five bilingual: Architecture, Business Administration, Communication, Law (LLB), Double degree Business + Law. 


\subsection{International University of La Rioja}

Business Administration (online) is the only degree which is offered in English.

\subsection{King Juan Carlos University}

This university offers eight degrees in English: Aerospace Engineering in Air Navigation, Business Administration and Management, Economics, International Relations, Marketing, Pre-primary Education, Primary Education and Tourism.

\subsection{Mondragon University}

There is a bilingual (Spanish-English) or trilingual (Basque-Spanish- English) degree in Business Administration.

\subsection{Pablo Olavide University}

This university offers a degree in Management and Business Administration in English which can also be taken in the double degree Business Administration + Law, (only Business Administration in English but not Law).

\subsection{Polytechnic University of Cartagena}

The only bilingual offer at the Polytechnic University of Cartagena is the degree in Business Administration ${ }^{3}$.

\subsection{Pompeu Fabra University} Economics.

Bilingualism at Pompeu Fabra is restricted to the degree in International Business

\subsection{Public University of Navarra}

The state-funded University of Navarra offers eight bilingual degrees, one of them double: Economics, Business Administration, double degree in Economics + Business Administration, Agro-food and Rural Engineering, Electromechanical Engineering, Industrial Technologies Engineering, Telecommunication Technologies Engineering, Computer Engineering.

\subsection{Ramon Llull University}

This university offers a degree in English: Management of Business and Technology, and another three bilingual, although the amount of courses available in the foreign langua-

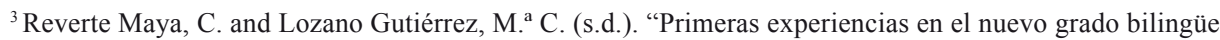
en ADE en la Universidad Politécnica de Cartagena", retrieved from http://web.ua.es/en/ice/jornadas-redes/ documentos/oral-proposals/241547.pdf
} 
ge is different: Business Administration and Management (80\%), Tourism and Hospitality Management (50\%), Business Administration (30\%).

\subsection{San Pablo CEU University}

This private university started bilingual programmes as far back as 2003 . Their current academic bilingual offer is the following: Pharmacy, Business Administration, Business Administration and Law, Business Administration and Marketing, Advertising and Public Relations, Advertising and Public Relations and Marketing, Law + International and European Law Diploma and Law, Journalism, Media Studies, Journalism + Media Studies, Journalism + Advertising and Public Relations, Media Studies + Advertising and Public Relations, Advertising and Public Relations + Marketing, and Architecture.

Some degrees include a semester abroad at Boston University or the University of Chicago.

\subsection{Technical University of Madrid}

No information is given on the existence of bilingual programmes at this university, but there is evidence of an experience in the Building Engineering degree, where first semester teachers tried to use English partially in their lectures and materials ${ }^{4}$.

\subsection{UEM (European University Madrid)}

This university has eleven degrees which are taught in English and three bilingual: Management and Entrepreneurship, Marketing and Commercial Management, Sports Management (specialization: Real Madrid Sports Management), Architecture, Biomedical Engineering, Design Specialization (Graphic Design), Biotechnology, International Relations, Journalism, Multimedia and Audiovisual Communication, Translation and Intercultural Communication. Bilingual degrees are: Pharmacy, Biotechnology, and Law.

\subsection{University of A Coruña}

The first and only bilingual degree in Galicia started in A Coruña: Business Admisnistration. It must be said that in this community, the lessons are taught either in Galician or in Spanish, according to the teacher's preferences or the degree requirements.

\subsection{University of Alcala}

At this university students can take two bilingual degrees: Pre-primary and Primary Education. Besides, there is the alternative of getting a bilingual degree taking at least $40 \%$

\footnotetext{
${ }^{4}$ Casaravilla Gil, A. (s.d.). "An Interdisciplinary Experience to improve the competences in English Communication in the UPM", retrieved from http://www.euatm.upm.es/innovacion/Comunicacion_INECE09-4. pdf
} 
courses in English and if there is evidence of attendance to the lectures. Those courses taken in English will appear in the diploma supplement. The course offer is not wide yet, except for the Polytechnic School: Architecture (10 ECTS: 1 course), Communications Electronic Engineering, Telecommunication System Engineering, Telecommunication Technologies Engineering and Telematics Engineering (102 ECTS: 17 courses), Computer Engineering and Computer Science (72 ECTS: 12 courses), Electronics and Industrial Automation Engineering (30 ECTS: 5 courses), Health Biology (6 ECTS: 1 course), Pharmacy (12ECTS: 1 course), Environmental Science (18 ECTS: 2 courses), Tourism (36 ECTS: 5 courses +1 elective), Business Studies (39 ECTS: 4 courses +2 elective), Law and Business Administration (9 ECTS: 1 course), Accounting and Finance (9 ECTS: 1 course), Economics (19 ECTS: 2 courses), Law (6 ECTS: 1 course), Audiovisual Communication (12 ECTS: 2 courses), Humanities (30 ECTS: 5 courses), Pre-Primary Education (60 ECTS: 10 courses), Primary Education (60 ECTS: 10 courses).

Courses related to English (Tourism-Business Administration, Cross Disciplinary Skills -ESP-), English Studies and Translation were not included in the previous list because they are usually taught in English, so they cannot be taken into account as a sign of introduction of bilingual programmes.

\subsection{University of Almeria}

This university offers a bilingual Economics degree and its aim is to establish a bilingual group for every degree in the long run.

\subsection{University of Balearic Islands}

The degree in Business Administration and Economics is offered in a bilingual.

\subsection{University of Cadiz}

This university started its Plurilingual Programme by offering a bilingual degree in Business Administration. Some courses in other degrees are offered not only in English but also in French and German.

\subsection{University of Cantabria}

This institution does not offer any bilingual degree, though there is an innovation project devoted to bilingual methodology and the process of elaborating teaching resources for bilingual lectures ${ }^{5}$.

\subsection{University of Cordoba}

It has implemented a Plurilingualism Promotion Plan which establishes a gradual introduction of bilingual courses. The English language is used at least on $20 \%$ or $40 \%$ of

\footnotetext{
${ }^{5}$ http://bilingualteachingunican.blogspot.com.es/2011/10/ensenanza-bilingue-universidad-de.html
} 
their total number of credits ${ }^{6}$. The Polytechnic school is the one with the highest amount of courses in English.

\subsection{University of Granada}

The University of Granada started a bilingual group for the degree in Primary Education in the academic year 2010/2011. Students take half of their courses in English. It has been one of the first Andalusian universities in offering bilingual undergraduate studies, and the rest are moving along: the universities of Almeria, Cadiz, Cordoba, and Huelva have designed several actions and programmes to favour multilingualism.

\subsection{University of Huelva}

This university offers some courses in English in the degrees of Primary School Education and Early Years Education.

\subsection{University of Murcia}

This institution has a bilingual group in Business Administration (70 people) and in Primary Education (65 people).

\subsection{University of Navarra}

This private university has been offering degrees in English for a long time; students can choose among nine, some of them double: English Economics, double Degree in Global Economics and Law, Double Degree in Global Management and Law, Management Assistance (ISSA), Humanities, Philosophy, Spanish Philology, Law + Anglo American Law Program, Law + International Media Program.

\subsection{University of Oviedo}

This university offers ten degrees which can be studied either in English or in Spanish: Business Administration, Commerce and Marketing, Accounting and Finances, Economics, Mechanical Engineering, Electrical Engineering, Industrial Electronics and Automation Engineering, Industrial Chemical Engineering, Computer Science-Software Engineering, and Tourism.

Students also have the possibility of writing and presenting their final dissertation in English. They may get a 'bilingual certificate' which will be added to their diploma supplement if they take at least $50 \%$ of their degree (that is one hundred and twenty ECTS) in English, either at their home university or abroad — within the framework of LLP-Erasmus bilateral agreements.

\footnotetext{
${ }^{6}$ Courses which devote $20 \%$ of their time to English language should reach $40 \%$ in two years' time.
} 


\subsection{University of the Basque Country}

More than one hundred courses are offered in German, French or English, but it should be kept in mind that there are many courses offered in Basque, as the institution has decided to offer every degree in Spanish and Basque (Cenoz, 2010: 27). Therefore, this author (2010: 29) states that the amount of courses in foreign languages is yet scarce but there is a tendency from bilingualism towards multilingualism.

\subsection{University of Valencia}

The University of Valencia offers seven degrees in English: Business Administration, Economy, International Business, Pharmacy, Medicine, Psychology, and Law.

\subsection{University of Valladolid}

Bilingual degrees at Valladolid range from Chemical Engineering, Telecommunication Engineering, Industrial Engineering, Computer Engineering, Business Administration, to Law.

\section{Discussion}

Translation and English studies (Barcelona, Huelva, Jaén, La Laguna) have not been considered among the bilingual degrees because both have always been taught in English or other languages (in the case of translation) and therefore, it is not a recent addition towards multilingualism.

There are some universities which offer Primary and Pre-Primary Education as bilingual degrees, especially in those communities where regional governments have established bilingual programmes in Primary and Secondary Education. It seems to be the right way to proceed in teacher training, meeting social expectations for student teachers. In this respect, there are some masters on bilingual education, but as it has been said, it falls out of the scope of this paper.

As it can be gathered from the information given along the previous pages, the most common degrees in English are those related to Business Administration, Economics, Engineering and the like. Bilingual options are more common for Social and Legal Sciences. Regarding the kind of institution there is a wider range of bilingual degrees at private universities than at state-funded ones; and the Community of Madrid the area where most bilingual courses are offered.

The European Higher Education Area (EHEA) has teetered thousand-year-old traditions and especially unmovable attitudes all of which fosters the introduction of new ideas and approaches to teaching at university level. One of the basic ideas of this 'Bologna process' is the necessity of having a good command of, at least, one foreign language (Ramos and Villoria, 2012). Surprisingly enough, current degree syllabi do not include a foreign lan- 
guage in most cases, but this important lack is balanced by introducing: i) courses in the foreign language in non-bilingual degrees, ii) bilingual degrees, or iii) degrees in a foreign language.

\section{Conclusions}

The situation in compulsory education in Spain favours bilingual education. Therefore, it would be quite unwise not to take advantage of that context and continue to expand the students' bilingual opportunities in their degree studies.

As it has been shown along the previous pages, Spanish universities are in the path of internationalization, bilingual/multilingual programmes offer a wider range of employment possibilities in the labour market at a European (or international) scale, guaranteeing our students the same opportunities as other European citizens. There is much to be done yet, but we are on solid ground.

Information on bilingual degrees should be available and easily reachable on the web. Visibility on the Internet is an unresolved matter for many Spanish universities concerning the topic. It makes no sense to look for courses in English by visiting every degree and their syllabi or distribution in semesters. On the contrary, there are some universities, usually those which have a large bilingual offer, which have an easily accessible link which shows their degrees in English at a glance?

\section{Bibliography}

Barrios, E. (2010). La educación bilingüe en Andalucía: análisis, experiencias y propuestas. Granada: Grupo Editorial Universitario.

Casal Medinabeitia, S. (2011). Implicaciones de la enseñanza bilingüe en centros educativos. Málaga: Ediciones Aljibe.

Cenoz Iragui, J. (2010). "El inglés como lengua de instrucción en la Universidad: nuevas tecnologías y multimodalidad", in Ikastaria, 17: 25-38.

Courses taught in English, (2011). Retrieved from http://portal.uah.es/portal/page/portal/portal_internacional/repositorio/50CatalogoAsignaturasIngles.pdf

Coyle, D., Holmes, B., and King, L. (2009). Towards an Integrated Curriculum. CLIL National Statements and Guidelines. London: The Languages Company. Retrieved from http://www. rachelhawkes.com/PandT/CLIL/CLILnationalstatementandguidelines.pdf

Dafouz, E. and Guerrini, M. (eds.) (2009). CLIL Across Educational Levels: Experiences from Primary, Secondary and Tertiary Contexts. Madrid: Santillana.

Dafouz, E. and Núñez, B. (2009). "CLIL in higher education: devising a new learning landscape", in E. Dafouz and M. Guerrini (eds.), CLIL Across Educational Levels: Experiences from Primary, Secondary and Tertiary Contexts. Madrid: Santillana, 101-112.

English taught programs, (2011). Retrieved from http://universidad.es/sites/default/files/documentos/ master2011.pdf

${ }^{7}$ Some information may not be as accurate as it should be due to the above-mentioned difficulties in accessing to key information on some universities' webs. 
Gallardo, L. del Amo, E., Sereno, E. Ferrández, M. M. and Satué, J. (2010). “Especial Selectividad y Elegir Carrera 2010", retrieved from http:/www.aprendemas.com/Guias/Selectividadelegir-carrera-2010/Descargas/EspecialElegirCarrera2010.pdf

García, O. (2009). Bilingual Education in the XXIst Century. Hoboken, NJ: Wiley-Blackwell.

García, O. and Baker, C. (2007). Bilingual Education. An Introductory Reader. Clevedon: Multilingual Matters.

Lasagabaster, D. and Ruiz de Zarobe, Y. (eds.) (2010). CLIL in Spain. Implementation, Results and Teacher Training. Newcastle upon Tyne: Cambridge Scholars Publishing.

Lasagabaster, D. and Sierra, J. M. (2009). "Immersion and CLIL in English: More Differences than Similarities", in ELT Journal, 64, 4: 367-375.

Lorenzo, F. (2002). "Stages in content-based instruction course development in English teaching at tertiary level", in A. Bueno, G. Tejada, G. Luque (eds.), Las Lenguas en un Mundo Global. XX Congreso Nacional de AESLA. Universidad de Jaén, 179-191.

Lorenzo, F. (2010). "CLIL in Andalusia", in D. Lasagabaster and Y. Ruiz de Zarobe, CLIL in Spain. Implementation, Results and Teacher Training. Newcastle upon Tyne: Cambridge Scholars Publishing, 2-27.

Lorenzo, F., Casal, S. and Moore, P. (2010). "The Effects of Content and Language Integrated Learning in European Education: Key Findings from the Andalusian Bilingual Sections Evaluation Project", in Applied Linguistics, vol. 31(3): 418-442.

Lorenzo, F., Trujillo, F., Vez, J.M. (2011). Educación bilingüe: integración de contenidos y segundas lenguas. Madrid: Síntesis.

Madrid, D. and Hughes, S. (eds.) (2011). Studies in Bilingual Education. Bern: Peter Lang.

Oferta de estudios en el distrito único de Madrid, (2011). Retrieved from http://www.uah.es/ acceso_informacion_academica/primero_segundo_ciclo/admision/preinscripcion/docs/OfertaEstudiosDistroUnicoMadrid.pdf

Ramos, A. M. and Villoria, J. (2012). "La enseñanza bilingüe en la Educación Superior”, in M. E. Fernández Fraile y J. Villoria (eds.) Enseñanza de la lengua y la literatura en la Universidad: innovación y calidad. Granada: Comares, 19-28 (in press).

Salaberri, M. S. (2010). "Teacher Training Programmes for CLIL in Andalusia", in D. Lasagabaster and Y. Ruiz de Zarobe (eds.), CLIL in Spain. Implementation, Results and Teacher Training. Newcastle upon Tyne: Cambridge Scholars Publishing, 140-159.

Vez, J. (2009). "Multilingual Education in Europe: Policy Developments", in Porta Linguarum, 12: 7-24. 